\title{
Configurações
}

Revista de sociologia

\section{Maria das Dores Guerreiro (coord.), Relações Sócio- Laborais em Micro e Pequenas Empresas, 2001, Lisboa, OEFP}

\section{Ana Isabel Couto}

\section{(2) OpenEdition \\ Journals \\ Edição electrónica \\ URL: http://journals.openedition.org/configuracoes/259 \\ DOI: $10.4000 /$ configuracoes.259 \\ ISSN: 2182-7419 \\ Editora \\ Centro de Investigação em Ciências Sociais}

\section{Edição impressa}

Data de publição: 30 junho 2010

Paginação: 183-184

ISSN: 1646-5075

\section{Refêrencia eletrónica}

Ana Isabel Couto, «Maria das Dores Guerreiro (coord.), Relações Sócio-Laborais em Micro e Pequenas Empresas, 2001, Lisboa, OEFP », Configurações [Online], 7 | 2010, posto online no dia 18 fevereiro 2012, consultado o 22 setembro 2020. URL : http://journals.openedition.org/configuracoes/259 DOI : https://doi.org/10.4000/configuracoes.259

Este documento foi criado de forma automática no dia 22 setembro 2020.

(c) CICS 


\title{
Maria das Dores Guerreiro (coord.), Relações Sócio-Laborais em Micro e Pequenas Empresas, 2001, Lisboa, OEFP
}

\author{
Ana Isabel Couto
}

\section{REFERÊNCIA}

Maria das Dores Guerreiro (coord.), Relações Sócio-Laborais em Micro e Pequenas Empresas, 2001, Lisboa, OEFP

1 É, na actualidade, amplamente reconhecida a relevância das empresas de micro e pequena dimensão enquanto um importante contexto de trabalho, dado o volume de emprego que representam e a sua predominância no tecido sócioempresarial português.

2 A investigação sociológica nesta área é, contudo, exígua, sendo o presente estudo, coordenado por Maria das Dores Guerreiro, uma excelente oportunidade para conhecer em profundidade a forma como se estruturam as relações sociolaborais nas micro e pequenas empresas. Os objectivos que presidiram à pesquisa foram compreender e caracterizar a realidade organizacional e as relações de trabalho de um conjunto variado de empresas de micro e pequena dimensão pertencentes a diferentes domínios de actividade.

3 Adoptando uma concepção alargada de relações sociolaborais, foi abordado um conjunto de dimensões na perspectiva quer dos empresários, quer dos trabalhadores. Assim, a análise das relações sociolaborais nestas empresas teve por base, por um lado, um conjunto de informações, tais como: as declarações dos empresários sobre a sua própria condição profissional, processos de recrutamento de pessoal utilizados e respectivos requisitos qualificacionais, tipo de vínculo contratual estabelecido com os 
trabalhadores, remunerações e regalias, tempos e intensidades de trabalho, qualificação e formação de empresários e trabalhadores, segurança, higiene e saúde no trabalho, relação com sindicatos e ambiente de trabalho; e, por outro, as declarações dos próprios trabalhadores face a estas dimensões, mas também em relação a aspectos estritamente relacionados com a sua condição, designadamente a trajectória profissional anterior, o percurso na empresa e a percepção face à autonomia e participação nas decisões da unidade empresarial em que trabalham. O livro encontrase organizado em duas partes, correspondendo cada uma delas a estratégias metodológicas distintas.

$4 \mathrm{Na}$ primeira parte, de cariz assumidamente mais descritivo, procede-se a uma caracterização das micro e pequenas empresas em Portugal a partir de dados estatísticos disponíveis em diferentes fontes, bem como a um mapeamento da legislação laboral e medidas de apoio direccionadas para as micro e pequenas empresas.

5 Na segunda parte, centrada na pesquisa empírica realizada, procede-se a uma caracterização densa dos vinte estudos de caso realizados em micro e pequenas empresas. As visitas às empresas consubstanciaram-se na realização de entrevistas aos empresários e aos trabalhadores, embora em número mais limitado, e ainda na aplicação de um inquérito de caracterização geral dos trabalhadores destas unidades empresariais.

6 Valerá a pena destacar duas interessantes tipologias propostas no estudo que decorreram de um esforço de articulação analítica dos diferentes dados empíricos recolhidos. A primeira reporta-se às diferentes modalidades de acesso à empresarialidade, tendo sido identificadas quatro principais modalidades: (i) a empresarialidade como iniciação à actividade profi ssional; (ii) a empresarialização da profissão anteriormente exercida; (iii) a empresarialidade como reconversão profi ssional, e (iv) a empresarialidade como alternativa ao desemprego.

7 A segunda tipologia diz respeito aos perfis-tipo de relações sociolaborais nas micro e pequenas empresas. Partindo da intercepção de duas dimensões centrais das relações sócio-laboraias, uma relativa à estabilidade no emprego - ou seja, regime jurídico da relação contratual (com as categorias "formal" e "informal") - e outra referente à empregabilidade - isto é, conteúdo formativo da relação de trabalho (com as categorias "qualificante" e "não qualificante") -, foi construído um espaço de atributos e defi nidos os respectivos tipos ideais. Os perfis-tipo das relações sociolaborais propostos foram: (i) empresas sustentadas; (ii) empresas formativas; (iii) empresas convencionais; (iv) empresas precárias.

8 Este estudo, para além de colmatar um vazio de pesquisa empírica nestes contextos empresariais, vem contribuir para um acumular de conhecimento sobre uma paisagem fragmentada como é a realidade das empresas de micro e pequena dimensão em Portugal. Um livro a explorar por todos aqueles que se propõem trabalhar este objecto de estudo. 


\section{AUTORES}

\section{ANA ISABEL COUTO}

Assistente de investigação do CIES, ISCTE-IUL

ana_isabel_couto@iscte.pt 